\title{
Revista BIBLIOTECA [“The Library" Review]: 1948-2018 - A Landmark in the Professional Community of Romanian Librarians
}

\author{
Elena Tîrziman, ${ }^{1}$ Maria Micle ${ }^{2}$ \\ ${ }^{1}$ University of Bucharest, Romania, elena.tirziman@litere.unibuc.ro \\ ${ }^{2}$ West University of Timişoara, Timişoara, Romania, maria.micle@e-uvt.ro
}

\begin{abstract}
The "Biblioteca" Journal, edited today by the National Libary of Romania, is a monthly publication best known in the Romanian library environment. It is the oldest publication dealing with library studies in Romania: in 2018, "Biblioteca" celebrates 70 years of existence. The journal first appeared in 1948, but over time, it changed its format, its periodicity, and of course its sections, but it consistently remained a standard for the Romanian journals specialized in librarianship. Furthermore, its presence in the professional community for such an extended period has had multiple meanings. Throughout time, the journal crossed various crises, and its pages bear the mark of its history. Today, the "Library" journal continues to be a binder of the professional community of Romanian librarians, although it faces the challenges of digital communication. This chapter will highlight the evolution of the Romanian Library Science as reflected in the pages of this specialized publication by analyzing the journal content with special focus on its thematic evolution.
\end{abstract}

Keywords: Romanian journal "Biblioteca" - 70 years of existence; communication; dissemination; information science; library; book role; knowledge; culture; Romania. 


\title{
Revista BIBLIOTECA ("The Library" Review): 1948-2018 - A Landmark in the Professional Community of Romanian Librarians
}

\author{
Elena Tî̀rziman, ${ }^{1}$ Maria Micle $^{2}$ \\ ${ }^{1}$ University of Bucharest, Romania \\ ${ }^{2}$ West University of Timişoara, Timişoara, Romania
}

\section{Introduction}

A professional and scientific field gains prestige and social recognition if it can assert its own specific identity. One can discuss a professional and scientific field whether that field generates the followings: it clearly states its subject matter; it defines its specific concepts; it develops its own methodology; it states its own laws; argues on models and theories; and it supports specialized publications which become the public space of the said field. From this point of view, one can argue that Library Science and the Science of Information is an recognized interdisciplinary field with a clearly stated status ${ }^{1}$ mentioned in the International Standard Classification of Education (ISCED) of UNESCO under the code 0322 Library, information, archive - however, Library Science does not always and everywhere enjoy an appropriate prestige.

Specialized publications contribute decisively to the prestige and status of a given domain - thus, this chapter will present the journal "Biblioteca" which celebrates 70 years of uninterrupted activity in 2018. Over these 70 years, the journal has intersected with the path of Romanian libraries and librarians, the two sides aiding each other throughout each one's development and difficulties.

The information presented in this chapter was obtained through content analysis of the journal. This was, of course, a quantitative analysis which went through the entire collection and was aimed at identifying and highlighting relevant information on the history of the journal, such as: sections, subject matters, cultural and bibliological personalities, and the importance of the journal for the info-documentary field.

\section{The history of the journal}

Since July 1948, the Biblioteca Journal has been a space for publication, information, debate, and professional formation. It first appeared under the title Călăuza cetitorilor [The Readers' Guide] (July 1948) and its aim was to record new publications. Shortly afterwards, it starts to develop as a publication dedicated to librarians and thus, in October 1948, it changes its name into Călăuza bibliotecarului [The Librarian's Guide], keeping this name until December 1964. Between January 1965 and December 1973, it appears monthly as Revista bibliotecilor [The Journal of Librarians]. The reforms in culture affected the publication: between 1974 and December 1989, it is

\footnotetext{
${ }^{1}$ European Commission. Education and training. ISCED 2013 code: 0322 Library, information, arcbive. bttps:/ / ec.europa.eu/ education/ resources/international-standard-classification-education-fields_ro (accessed November 28, 2017).
} 
published as Biblioteca: buletin trimestrial de biblioteconomie/bibliologie [The Library: Quarterly Bulletin of Library Sciences]. Within this period, it appeared as a supplement of the journals Indrumătorul cultural [Cultural Guide] (December 1974 - December 1979) and Cîntarea României [The Song to Romania] January 1980 - December 1989).

The year 1990 represents a new beginning for the publication: it appears as a new series published by the Ministry of Culture with the title Biblioteca: revistă de bibliologie și știinta informării [The Library: Journal of Library and Information Sciences]; afterwards, starting with 2009, it started to be published by the Romanian National Library (which also publishes the following journals: Revista Bibliotecii Naționale a României, Revista Română de Istorie a Cărţii, Revista Română de Conservare şi Restaurare a Cărţii $)^{2}$.

\section{Subject matters, content, sections - evolution in time}

Starting its very first years of existence, the journal becomes a benchmark for professional formation, because of three main reasons: the publication of fundamental specialized literature; the creation of a section dealing with the field's theory and practice; the active support of professional manifestations and continual formation in Library Science. The publication contains articles on the organization of courses for librarians, the professions included in the profile of the librarian, the attributions of various professions in Library Science, proposals for improving field-related activities, etc.

The cultural dimension of the journal should also be highlighted. The Romanian and foreign cultural and documentary heritage present in libraries is presented to the wide public. Significant personalities of the time authored articles - some of them being the academician Virgil Cândea, mathematician Grigore C. Moisil, literary historian Serban Cioculescu, historian Alexandru Zub.

Today, "Biblioteca" (ISSN 1220-3386) is still connecting the members of the professional community of Romanian librarians, but it faces the challenges of digital communication. Still edited by the Romanian National Library, it is published monthly in printed format, as an informative bulletin addressed to all types of libraries and its articles continue to be written in Romanian with contents and abstracts in English. ${ }^{3}$

The current sections of the journal are the followings:

- Repere profesionale [Professional Benchmarks] - it contains Library Science theory and scientific research

- Viața bibliotecilor [The Life of Libraries] - presentations of current activities in all types of libraries (events, projects, models of successful practices)

- Metodologie [Methodology] - usually contains materials by the Romanian National Library which functions as methodological coordinator

- Patrimoniu [Heritage] - section on collections and library values

- Meridian bibliologic [Library Science Overview] - section on the personalities of the field and events

- Galaxia Gutenberg [Gutenberg Galaxy] - miscellaneous section, library calendar, reviews, documentary summaries, debates. ${ }^{4}$

\footnotetext{
2 Reviste BNR. http://www.bibnat.ro/Reviste-BNR-s223-ro.htm (accessed December 20, 2017).

${ }^{3}$ See the journal with all its information here: http://www.bibnat.ro/Biblioteca-revista-de-bibliologiesi-stiinta-informarii-s224-ro.htm (accessed December 20, 2017).

${ }^{4}$ http:/ / www.bibnat.ro/Biblioteca-revista-de-bibliologie-si-stiinta-informarii-s224-ro.htm (accessed

December 20, 2017).
} 


\section{"Biblioteca" ("The Library" Review) - a benchmark in professional formation}

During the period when there were no graduate courses on Library Science, the journal played a significant role for the formation of librarian professions. The University of Bucharest had a Library Science Department within the Literary Faculty between 1953 and 1958. The courses initiated by N. Georgescu Tistu at the University of Bucharest were continued by Mircea Tomescu (1960-1969) and Dan Simonescu (1970-1972). Between 1963 and 1970, Professor Dan Simonescu coordinated a department of Library Science where the courses had a length of three years. Starting with 1968, under the coordination of the same professor, the $\mathrm{PhD}$ studies in the field were inaugurated.

Since 1990, after the fall of communism, Library Sciences return as a form of institutionalized education within universities such as the University of Bucharest and other universities in Romania from the cities of Cluj, Timișoara, Sibiu, Braşov, Oradea, Suceava, Târgoviște. Of these universities, the Library Science departments from București, Cluj, Sibiu, Timișoara (as a post-university programme) still function. The new programmes proposed the professional formation of individuals in the areas of Library Science, Information and Documentation, and the Science of Information, for professions in a permanent state of transformation because (due to their content represented by documents and information). University formation assures the establishment of the following professions: librarians (cataloguing, indexing, librarians in relation with the public, librarians for reference services), editors, archivists, documentary specialists, database specialists, specialized information intermediaries, and other professions in the field of Information Sciences.

In the communist period, the specialized university formation was sporadic and was done through optional courses - thus, the ones who worked in libraries were gradates of other specializations, usually of humanities, who then needed initiation and continuous formation courses. This is the point where the importance of Biblioteca as a professional support becomes apparent. The journal collections of the '1950s, '60s, "70s, and '80s display articles with varied subjects on the profession, as well as articles with a theoretical and practical perspective. The subject of theory and practice in Library Science is dealt with in approximately half of the journal content. This is done in an extremely diversified way (from a thematical point of view), starting from subjects of wide general interest to particular aspects for small communities of specialists in the field. The articles and studies specifically refer to aspects and professional competences ${ }^{5}$ in Library Science and the Science of Information - furthermore, one can observe an evolution of these articles throughout time. Since the journal's very beginning, there was a clear preoccupation with the assessment and consolidation of the Library Science professions so that any Romanian librarian (regardless of the type of library they work in and of their geographical area) could have at disposal articles of interest while being up-to-date with the field and while belonging to the community. Furthermore, the most relevant aspect of the journal's preoccupation with the profession was that it offered information in such a way that the work quality of the Romanian librarian was not different than the work quality of librarians from representative European libraries.

Should one write a textbook on Romanian Library Sciences solely with information gathered from the journal's collections, a complex document would result which would

5 Elena Tîrziman; Maria Micle. "Adapting Librarians'Professional Competences to Current Requirements through Initial Education and Lifelong Education," in European Journal of Social Sciences Education and Research (http://ejser.euser.org/), vol. 6, no. 2 (2016), 161-166.

http://journals.euser.org/files/articles/ejser_jan_apr_16/Elena.pdf (accessed November 28, 2017). 
encompass all Library Sciences sub-fields of interest as well as the historical evolution of the field. The development and the organization of the collections is a thoroughly debated subject touching on aspects of evidence (considered important in the 1950s when the society was being reorganized after the instauration of communism), acquisition, the organization and reorganization of the legal deposit, supplementing collections by "the collection of libraries" as a method of centralized acquisition from publishers (in the 1960s). National and international publication exchange becomes important for the Romanian scientific communities, especially in the 1970s, although one can notice a decrease in these activities in the 1980s because of ideological reasons such as Romania's imposed communication limitation with the western world. Publication processing is one of the best represented themes in the journal. Thus the theory and practice of publication processing (cataloguing, indexing, the organization of catalogues) were presented with the main aim of describing its methodology, by instructing and helping the library community to work in a unitary way. The international cataloguing norms were repeatedly presented, together with the specific standards for publication processing, the instruments needed for work, guides and methodologies, and examples (this has been happening since the 1960s up until the present day). Subjects such as information and documentation in libraries are frequently found in the articles of the 1970s and '80s, while subjects regarding the digitalization of libraries and digital information started to be dominant in the 1990s towards the years 2000.

After the 1990s, the university curriculum reintroduces courses of Library Sciences, thus the Biblioteca journal starts to collaborate and support the academia. Although the editorial production often surpasses the reading and assimilation capacity of the specialized bibliography, the Romanian journals of Library Sciences are still not frequent, thus Biblioteca remains a leader in popularity, based on its subscriptions and visibility.

Alongside professional articles, scientific articles are increasingly published, thus the journal starts to be open to international authors who present their experiences in the field. Furthermore, the journal is more and more cited in the thematical bibliography offered to students.

\section{Personalities and the journal}

Several generations of specialists contributed to the consolidation of the Library Sciences field in Romania and they used the publication as a space for information and professional debates. Reading the journal issue by issue, one can notice the evolution of the field in Romania as well as matters such as: keeping the profession up-to-date and modernizing it, theorizing Library Science activities, the dissemination of good practices in the field, the collaboration between libraries, etc. This way, one the journal highlights certain methodological issues of the field, such as: how public and scientific libraries were organized; which were the principles of collection development; which norms were at the basis of publication processing; how catalogues were organized; how bibliographies were created; how information and documentation activities were done in libraries; etc. A significant number of articles were signed by representative names - thus these texts (which often also presented portraits of renowned Romanian Library Science specialists) became fundamental in the field. Furthermore, the preoccupation of research and documentation is apparent throughout the journal content.

Therefore, over a century ago, Ioan Bianu, managed to create a Library Science school within the Library of the Romanian Academy, to create the basis of the field's activity in Romania. Furthermore, he defined the function and organization rules of a library (based on unitary norms, theories, and practices), thus creating a library which then became the first national library of Romanians. Nerva Hodoş, who was schooled at Bianu's school from the 
Library of the Romanian Academy, imposes the reorganization (based on modern scientific criteria) of Library Science activities. Most significantly, he imposed the reorganization of bibliographical articles - a domain in which he was deeply involved. Nicolae Georgescu Tistu takes the Library Science school to an institutionalized environment. As a docent in Library Sciences, he teaches specialized courses at the Higher School of Archives and at the Literature Faculty of the University of Bucharest. Ioachim Crăciun has a remarkable teaching career in Cluj and contributes fundamentally to the development of the field with significant writings. Dan Simonescu ${ }^{6}$ enriches the field with a historical, theoretical, and research dimension, thus essentially contributing to the evolution of the book-related fields. Corneliu Dima Drăgan continues the activity of Professor Simionescu and directs his teaching and research activities towards the theory and practice of Library Sciences, as well as the history of libraries. Mircea Tomescu was preoccupied by the theoretical and practical aspects of the field and published his research thus defining and presenting his concepts in an remarkable work on the history of the Romanian book. Gabriel Ştrempel ${ }^{7}$ modernizes the Library Science school of the Library of the Romanian Academy, by connecting his path with that of this library and by contributing to the realization of several monumental papers in the field. Gheorghe Buluță was one of the most representative followers of Dan Simionescu and continued the work of the famed professor by his contribution to the theoretical and practical development of the Romanian Library Studies. Mircea Regneală ${ }^{8}$ discusses the entire contemporary problematic of Library Sciences, touching on theoretical and applied research, thus having a significant contribution to the support of today's education in the field.

Several other names were involved in the editorial activity of the journal. They supported its publication in sometimes extremely difficult situations being aware that Biblioteca is a fundamental professional benchmark for the Romanian librarians and libraries. Some of these names are the following: Grigore Botez, Getta-Elena Rally, Barbu Theodorescu, Atanase Lupu, Angela Popescu-Brădiceni, Corneliu Dima Drăgan, Ioana Lupu, Corina Costopol, Emil Vasilescu.

The Biblioteca journal, through the specialists of the field with recognized realizations, assured a type of advisory environment for librarians, creating a bridge for dialogue between specialists and librarians.

\footnotetext{
${ }^{6}$ The fundamental bibliographical work used for the identification of old Romanian patrimony books is: Ioan Bianu, Nerva Hodos, Dan Simionescu, Bibliografia românească veche. 1508-1830 [Old Romanian Bibliography. 1508-1830]. I: 1507-1716 (Bucharest: Academiei Române, 1903); II: 1716-1808 (Bucharest: Academiei Române, 1910); Ioan Bianu, Dan Simonescu, Bibliografia românească veche. 15081830 [Old Romanian Bibliography. 1508-1830] III: 1817-1830 (Bucharest: Academiei Române, 1936); Ioan Bianu, Dan Simionescu, Bibliografia românească veche. 1508-1830 [Old Romanian Bibliography. 1508-1830] IV: adăogiri şi îndreptări [Additions and Corrections] (Bucharest: Academiei Române, 1944).

7 Gabriel Ștrempel also coordinated the following summary works: Bibliografia românească modernă, 1831-1918 [Modern Romanian Bibliography, 1831-1918] 4 volumes (Bucharest: Editura științifică și enciclopedică, 1984-1991); Catalogul manuscriselor românești [The Catalogue of Romanian Manuscripts] 4 volumes (Bucharest: Editura științifică și enciclopedică, 1978-1992).

${ }^{8} \mathrm{M}$. Regneală headed the editing of the collective work: Tratat de biblioteconomie [Treatise on Library Studies] 2 volumes (3 books) (Bucharest: Asociația Bibliotecarilor din România, 2013-2016). The third volume is currently being published.
} 


\section{The importance of the journal for The National Romanian System of Libraries ${ }^{9}$ (Sistemul National de Biblioteci din România [SNBR])}

Throughout its 70 years of activity, the journal was an editorial space in which all types of libraries were involved, including the SNBR as a whole. The journal helped libraries to remain united and fulfill their specific aim, even in difficult social and historical moments. Biblioteca thus became a public space for Library Sciences and a forum for professional questions and answers, while being an exhibition of library presentations, good practices, examples of representative activities.

While large libraries such as the Romanian National Library, the Library of the Romanian Academy or the university libraries are usually present in the journal, also smaller school and public libraries are present. They are motivated by the will to make their presence visible in the both library space and in the Romanian cultural space of their specific interest.

The Biblioteca journal was the main methodological support for SNBR thus contributing to the promotion of norms, standards, guides, and unitary work methodologies for all libraries in the system. Between the 1970s and 1980s, when the access to international information was particularly difficult, the journal compensated this phenomenon by trying to promote, on the largest professional scale, translations for the specialized literature, conferences, and other types of activities which aided the library professions. Without exaggerating, it can be asserted that the journal Biblioteca had a significant contribution to the synchronization of the Romanian Library Science reality and that of the international reality (Russian on several stages, as well as European and North American).

It is important to note that SNBR regards the journal as a forum of all Romanian libraries, as a professional and editorial space of all libraries and librarians.

\section{The perspectives of the journal in today's digital information context}

The dependence on the technological innovation is increasingly accentuated today, thus electronic resources offer specialists abounding information from all over the globe. However, because this information is preponderantly published in English (the new scientific language), the accessibility of to these resources depends on an advanced knowledge of the language and on the level of digital alphabetization. Because of the need of internationalization and integration in the "global village," researchers are motivated to rather publish in foreign journals and in a language of international circulation in order to receive international visibility. Therefore, original productions and specialized literature in Romanian are increasingly poorer. As a consequence, one can notice the creation of a distance between the scientific (elite) environment and the professional one, which, generally, tries to integrate the innovative ideas in its own rhythm.

Scientific journals, just like the entire publishing field (both characterized by the diffusion of novelty) is currently acclimatizing to the digital environment. Therefore Biblioteca has once more the opportunity to assess its role in the Romanian community, by popularizing and disseminating science to a large Romanian-speaking professional environment. Contrary to the printed publication formats, online publications allow communication in two ways and favour rapid reaction. Today, Biblioteca published its summaries and abstracts bilingually (in Romanian and English) and, since 2010, it is indexed in EBSCO and ProQuest. The next step necessary for keeping and enforcing its visibility is transforming the journal in an open access journal. This way, its content could better reach its target audience who could be involved and interested in the professional activities of librarians.

\footnotetext{
9 SNBR is formed of two main types of libraries: public libraries (county/city/local libraries) and educational libraries (academic and school libraries). The National Library has a methodological influence over libraries, especially the public ones.
} 


\section{Conclusions}

Being both a cultural and a specialized publication of Library Sciences, the Biblioteca journal is a channel for professional communication and opinion formation. It managed to be a constant appreciated presence in the specialized Romanian space, favouring publications from the entire SNRB network. Having reached its $70^{\text {th }}$ anniversary, after an often difficult and questioned path, the journal continues to support libraries and librarians in their professional destiny. There are only a few other specialized publications in Romania with can pride with such a longevity. Biblioteca is addressed to all libraries from the SNRB network, thus its role of defining the status of Romanian Library Sciences must be highlighted. Furthermore, the journal must be supported so that it remains in the professional editorial space of Romanian libraries and librarians.

\section{References}

"Biblioteca". Ed. Romanian National Library. http://www.bibnat.ro/Biblioteca-revista-debibliologie-si-stiinta-informarii-s224-ro.htm (accessed June 28, 2017).

Biblioteca Collection. 1948-2017.

Biblioteca, număr aniversar - 65 de ani [Biblioteca, anniversary issue - 65 years]. Bucharest: Editura Bibliotecii Naționale a României, 2013.

Buluță, Gheorghe and Victor Petrescu. Galeria bibliologilor români. Portrete [The gallery of Romanian Library Sciences specialists. Portraits]. Târgovişte: Biblioteca, 2013.

European Commission. Education and training. ISCED 2013 code: 0322 Library, information, archive. bttps:/ / ec.europa.eu/ education/ resources/international-standard-classification-educationfields_ro (accessed November 28, 2017).

Tîrziman, Elena and Maria Micle. “Adapting Librarians'Professional Competences to Current Requirements through Initial Education and Lifelong Education". In European Journal of Social Sciences Education and Research (http:// ejser.euser.org/) 6 (2016): 161-166. http://journals.euser.org/files/articles/ejser_jan_apr_16/Elena.pdf (accessed November 28, 2017). 


\section{D.}

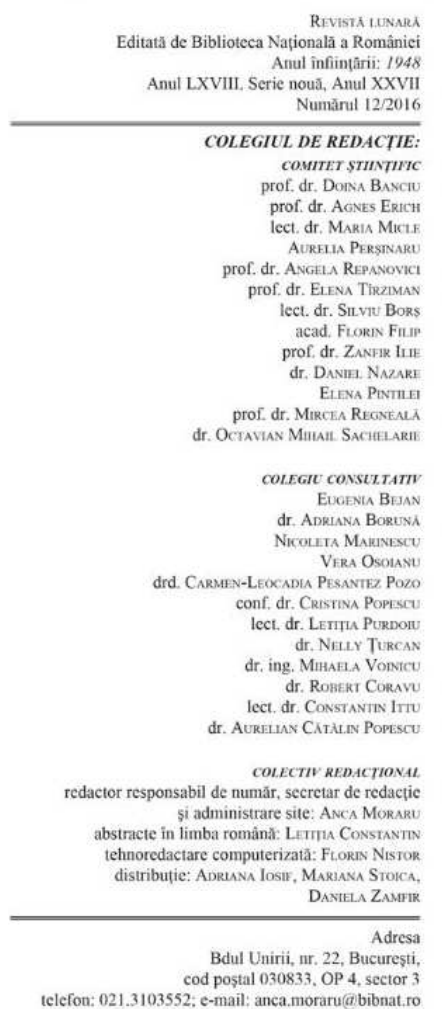

\section{Summary} EDITORIAL.

School Library - an Essential Factor in Fostering the Pupils' Interest in Reading Gabriela Harea HIGHLIGHTS ON LIBRARIANSHIP Reinventing the Sctiool Libranan in the Digital Age Florina Brat. ON ROMANIAN LIBRARIE

A History of 90 Years. "Petre Anghel" Baileşti Municipal Library Janeta Vhad _ p. p. 35 New Projects at "Trantilvania" Lniversity in Brasov - TUBV p. 362 GUIDELINES. LEGISLATION. SYNTHESES 21 Excelleat Reasons for Excellent Libraries (part II) Bibliothek und Information Deutschland ....... 365 CULTURAL HERITAGE

Petre P. Negulescu-a Complex Personality of the Romamian Culture 65 Years since His Death Cristina Bacin LIBRARY ABROAD

INELI-Balkats Project or about the Power of a Network Raluca Man.

GUTENBERG'S GAL.AXY

20th Edition of the International Children's Book Fair in Chişinău. 14 to 16 April 2016

Adriana-Elena Borunã, Andra Năstase.......... p. 37 Virtual Traditional Catalog of the National Library of Romania: Online Aecess to Infornation and CrowdCataloguing through the Book-a-Book Platform Luminita Gruia

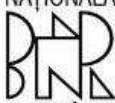

\section{ISTA \\ HOCA}

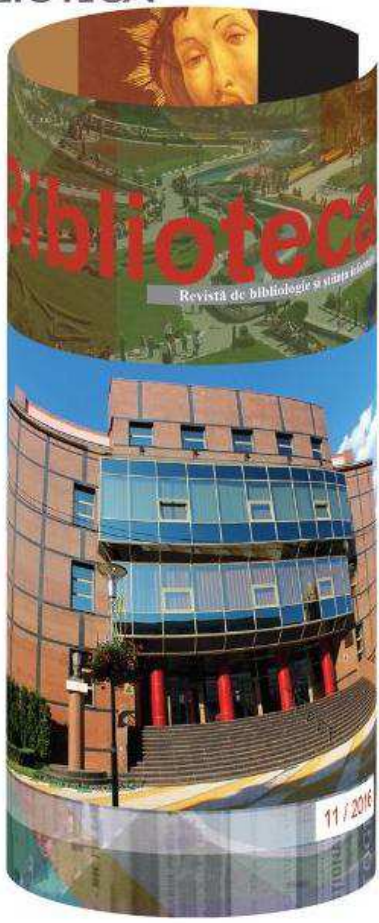

ABONAMENTE

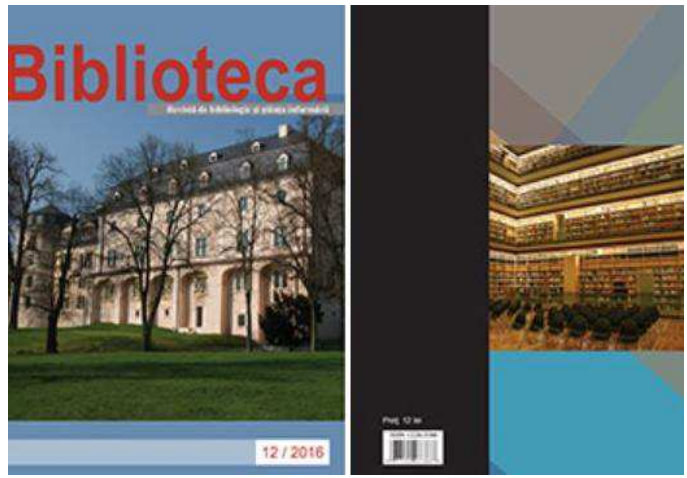

Fig. 1. Example of one of the journal's issues:

the editorial board, the table of contents and the cover Source: http://www.bibnat.ro/Ultimul-numar-s239-ro.htm 